\title{
Resolution of Financial Discipline's in Grow up Economy and Keeping Away from Prodigality Instance Behaviors Unbalance Improve Strong
}

\author{
Mojtaba Mali, Hossein Niavand \\ Department of Management, East Azarbaijan Science and Research branch, Islamic Azad University, Tabriz, \\ Iran \\ Research scholar, phD in statistics, India
}

\begin{abstract}
Credits are like smooth fluid matter which cover the body of organization system and are like a fuel which guides the operation of executive systems into stages of application and actuality. In other word it is like a balance which has credits on one pan and operation on the other pan of a scale. On this direction the hypothesis of this research is that: (1) Resources must be allocated in a strategic program frame work. (2)It should be assured that resources allocated are spent for the aforesaid program. (3)The spending situation should be supervised. Since these above mentioned measures are necessary, then it is recommended that all the factors of desired budget are used and efficiency of system and its yield earned from executive operation is supervised and necessary financial resources versus human and plants and equipment resources are in equilibrium so that by reduction of financial resources there would not be any disorder in volume of executive operation. The writer of this article is trying to look attentively and clarified the dimensions of selected subject by use of "descriptive - analytic" research method.
\end{abstract}

Key-Words: Budgeting, Credits, Financial Disciplines, Financial Resources Management, Prodigality and Ravishment.

\section{Introduction}

Expansion capitalism economies were competition between technology progress and population development. That for some time technology progress to settle at the head but time will end (or affected with standstill) and economy will take descending revolution. Technology progress paludar fever is dependant to capital fullness. That is lying for become machinery and work divide. With increasing - growth and development of technology and variety of activities, make it necessary to evaluate and care the expenses of any activity in order to settle the problem of attracting credits and correct allocations.

[2] From the start of Budgeting till 1965 the government badger was prepared traditionally or according to the norms and the main focus was on controlling the expenses of any ministry [3]. When the mean of budget was just financial controlling, classification of expenses and organizational classification were considered as the main budgeting classification budget without planning id little a huller that e shoot in darkness and then say we wanted it hit that spot, while we must first recognize the target in shut gun. Budget is a giant which camas annually with great immensity and if channels are not prepared for it, it chooses its own way inevitably and may cause same damages. But if it is dive rented to predator mined ways and channels it can be curbed.

[14]

Budgeting

\section{Definitions}

The process of development in mid- tern plan which includes preparing, arrangement and suggesting budget, approval, performance and supervision on budget in a financial year. Budgeting is a server thought of limited financial resources versus infinite requirements so that organic and various connections between fanatical and infinitival resources were considered. (Saaidi, 2006:227)

\section{Credit}

Includes an amount (of money or investment) for certain spending in order to achieve goals and implementation of government plans which are approved by Islamic council "material 7 of public accounts rules" credit is the approved limit of expresses [7]. 


\section{Performing ape rations}

It means current activities and reconstructive projects of implementing systems which are determined in annual program. "Joint 1 of material 1 of plan and budget rules approved in 1973" is collection duties which are given to implementing organization (system) bused an duty's describe.

A group of duties which are given to implementing system and it's credits are met by general government budget.

Implementation of duties and administrative operations are given to implanting organization by means of rules and can be based upon approvals of ministry cabinet or economic council or approvals of an efficient author. (Farzib, 2001:449).

\section{Budgeting}

Estimation of operations volume id in existing state to convert to credits by avoiding priorities.

The process of decision mulling and allocation of required resources in order to achieve goats in an organization. The process of activity to provide budgets in an organization is called "Budgeting". (Saaidi, 2006:227)

\section{Budget and management}

The main definition which is made for management is: management includes appropriate and efficient application of material financial and human resources in order to achieve predetermined goals. [6] Organization

Organization may were industrial and produce company - private commercial company - government ministrysport and club receptive - out public utility Institute - ungorer - nment - university - unit of army or Islamic banks. [15]

Public Expenditure Management Handbook [17]. This was influential in developing a broader view of the budget process, stressing the importance of understanding the links between policy, planning and budgeting for an effective PEM1 system.

Aid and Public Expenditure: A Guide [13]. This working paper is closely based on the relevant chapter of the DFID Economists' Manual. It outlines the basic elements of the budget process, and deals with the specific issues relating to donor agencies providing direct support to public expenditures.

Understanding and reforming public expenditure management: Guidelines for DFID [4]. This document provides a more concise presentation of the budget process and related elements of a public expenditure management system. It places greater emphasis on a framework for diagnosis of problems in Public Expenditure Management (PEM), and how that analysis can be translated into the design of systemic reform.

A Guide to Budget Work for NGOs [10]. In contrast to the three documents above, which all address primarily donor agency staff and consultants, this guide addresses civil society actors wishing to engage in 'applied budget work', for the purposes of strengthening the social and poverty reduction content of budgets and related policy frameworks.

\section{Budget and process of management}

Control mainly is for that credits not to be wasted or spent illegally or in an extravagant manner. [1] Formal accounting and budget shills can be used in order to direct spending budget into ways which are prescribed by people and legislations.

Inspectors can prevent these employees who are willing to embezzle government facilities. Governments found also must be spent efficiently and legal. [2]

\section{View point. Budget and credits system}

"Budget and credit" system is designed for those organizations whose financial performances are based on standard method of announcement, allocation and commitment of budget. In such a system which acts in close relation with "financial accounting" the budget structure of stanzas of the organization is defined beside the structure of system's "financial accounted and each of the stanzas of the budget is allocated to an account of "financial accounting"." Budget and credit" system acts in a way which includes the whole circle of budget from approval till allocation and commitment and spending of budget in relaxed unit. Relation with "financial accounting" system leads to exchange of information between two system .In such a way the recorded

\footnotetext{
1 - Public Expenditure Management
} 
accounting documents about budget accounting enter into "budget and credits" system and after being confirmed by related body are recorded in budget notebooks.

\section{Budgeting short comes}

1. Budget does not indicate policies of organization and in general depended on financial statistics for a period of 12 month.

2. The basic factor in values production of a organization like spiritual investment and efficient factors of the organization and operational processes and in general invisible possessions and their role in income producing of the company are not considered (in budgeting). It can be said such factors perform 50\% to $90 \%$ of values of many companies.

3. The main role of textual budget is to determine rates and a certain limits for development and quality and minimum for expenses in order words, budget is a tool for controlling goals and predetermined operational and financial plans in same cases in contrast with increasing competitive current situation.

4. In same conditions and countries with a high rate of inflations, budget figures lose their meaning and credits as a tool of evaluation. Rapid changes in plans and activities have similar effects on efficiency of budget.

5. Operational budget are provided based on past periodical figure and adding a percentage for future periods. Evaluation and a controlling is also practically on the basis of predetermined figures.(without paying the attention to creativity and potential for conductive architectures).

6. In providing budget usually the tendency is toward figures and budget making so that the results of activities and level of performance are estimated lower than achieving and the required resources are predicted more than reasonable, so in many cases unjust rewards are given with making comparison between real cast and false budget statistics. [5]

\section{Management principles}

Customers: concentration on increasing the number of customers and development the relations with them, instead of determining sailing limits $t$ customers.

Answer shit: forming work teams which are responsible to the results of their own operation and performances instead of response according to dictating goals in an organization pyramid.

Measure of performance: making comparison with rivals in neither marker nor internal measure.

Creativity: freedom and creativity of teams instead of controlling them in predetermined goals.

Leadership: basic leadership with main goal of creating values instead of using constant budget and inflexible rules and prescriptions.

Information's: using information's jointly instead of making limitation for a special to access information.

\section{Principles of processes}

Cools: appointment of ambitious goals with continued improving performance instead of appointing contact annual goals.

Rewards: paying rewards based on collective and common success related to comparison of performances instead of achieving the constant annual goals.

Planning: to convert planning to a continued process not on annual event.

Controls: to control based on key performing indicators instead of using difference of constant goals and plans.

Resources: to allocate resources based on requirements instead of allocating resources in annual budget's frame work.

Conditions: Active and everlasting coordination between organization's component.

Extra budgeting does not mean a new tool or skill but a management's philosophy based on principles taken from real experience of a searching and flexible organization's which provides the possibility and authority of running united(of organization) with maximum of confusing. [5]

Fight against financial corruption after occurrence

Although this everlasting motto which says "prevention is better than treatment" is a nice motto, but in some cases preventions cannot play any positive role and also supervisions on the time of operations is not efficient. In such cases according to the sayings of Islamic Republic's supreme leader the justice's strike must be hit to offenders of laws with administrative and punishment guarantees. In this section of ruling system of our country, thanks to goal, there are various rules and provisions which are related to the stage after occurrences of offense. [12]

Strategies economy expansion apply by exp aning countries (from 1960 until 1980) can point to this cases

Monetary strategies 
This strategy promotion marked signs is concentrated guidance for well being reference allocation. Almost in act this strategy applies during critical term.

\section{Free - economy strategy}

This strategy have view to foreign and is some of exist monetary strategy but not of all them . this strategy also is for reference. [11]

\section{Conclusion}

Wasting or ravishment and dissipation are considered as unbalanced behaviors. Wasting is to spend something on its position an but more them usual and needed amounts and dissipation is to spend something nor in its position but in a case which is not necessary, since efficient using in dimension of best allocation and in dimension of consumption of resources are considered as two behaviors toward equilibrium, therefore paying attentions to wasting and dissipation seem. Very necessary, because these two behaviors lead to wasting of resources including natural financial and human resources. Wasting: and dissipation can be investigated in dimensions of little and huge quantities. In level of little quantities, unnecessary extravagancy and over using of water and energy, material need, paper which are in the circle of current consumptions are among the main example of wasting. But in level of hugs quantities, wasting mean inappropriate allocation of financial, resources for projects and urgent plans. The officials of management and planning organization of the country which are responsible. For arrangement and allocation of budget must invest how resources should be allocated and consumed. Also, It must be noticed that in: pending resources. Saving must be observed. The fallowing measurements are necessary in this respect.

1. Resources must be allocated in strategic and purposeful programs.

2. It must be assured that allocated resources are used for related program according to priorities.

3. Ways of spending must be taken under supervision and control.

In first stage which pays: attention to the necessary of best allocation is among the responsibilities of countries management a planning organization. In this stage there must he attempt to make priorities for requirements and credits are allocated according to the real need of organization.

The second please which is related to taking best advantages of allocated resources is among the responsibilities of state administrative organization and also organization which are given responsibilities to have continual supervision on

Credits are spent according to real needs and arms and 2. allocated credits are spent toward real needs and by means of most efficient methods[9]. Therefore if "the budget and credit" system is inaugurated in an organization leads to the fulfillment of goals listed below.

- Facility in prediction of budget for future year.

- Clearness of budget relaters with units of organizations.

- The possibility of connection and taking online report from independent and dependent units of organization.

- Exchange of information with "fanatical accounting" and prevention of re-doing.

- Creation of militarized budget office and various statistical controlling reports.

- To have control on spending budget of units and related branches and also budget controlling in state account in economic dimension is important for following reasons.

- Improvement of given service to people.

- Taking the best advantages of resources and existent potentialities.

- Providing conditions to standardize state-run organization's services.

- To increase motivation of employees and managers and granting needed authorities to them.

Replacing controlling the result of activities instead of controlling the stage of doing the job.

The operations of organization are efficient and economic provided that they lend to the production of goods or presentation of expected and useful services, because if there is no request for best efficient manufacturer, he has to end its activities. Deposit of this fact, most of state-run companies still work, and the basis of this principle how to do the apparition instead of insisting on appointment type and reason of the apparition.

\section{References}

[1] Anderson J, Public Policymaking, Boston, New York: Houghton Mifflin Company, 1994, p167.

[2] Aronson R, Public Finance, New York: McGraw-Hill Company, 1985, 251.

[3] Cento Central Treaty Organization. Budget Administration, agency For International Development, Tehran: Ankara Central Treaty Organization, 1973, 6(2): 7-9, p68.

[4] DFID. Understanding and Reforming Public Expenditure Management: Guidelines for DFID, Version 1, 2001.

[5] Fakhrian A, Farewell Budget, Tehran: Hesabdar Publications, 2006.149(1): 1-4, p146.

[6] Farejvand E. Return Of Arrangement Till Central Of Budget, The Tenth Edition, Tehran: Foruzesh Publications, 1973 p177.

[7] Farzib A, Stare Budget In Iran, Tehran: The Tenth Edition Publications Of Center For State Management's, $2001, \mathrm{p} 449$.

[8] Hemmati A, Operational Planning, Tehran: Publication Of Assistance Of Education And Planning Budget, $2007, \mathrm{p} 2$. 
[9] Industrial Management Organization, Ravishment, Little and Huge Viewpoint, Tehran: Monthly Tadbir Publications, 1997, 62(1): 52-58, p 53.

[10] International Budget Project, Third Conference of the International Budget Project, Mumbai, India, November 2000. Papers presented and notes on discussions. www.internationalbudgetproject.org, 2001

[11] Kit G, Waies Economy Expansion, Raghfar H, Hashemi MH, Tehran: NAI Public, 2003, 4(1): 12, p78.

[12] Mennatineshad S, Station Of Fighting Against Fanatical Corruptions In Rules And Provisions And The Role And Responsibility Of Supervising Organization Of Regime In Mentioned Fight, Tehran: Electronic Rules Publication, 2005, 1(2): 1-2. P5.

[13] Mick F, and Fozzard A, Aid and Public Expenditure: A Guide ODI Working Paper, 2000, p141.

[14] Public Administration Service, Modernizing Government Budget, Chicago Publications, 1964, p43.

[15] Saadat E. Managent of Human Reference, 12 Impressions, Tehran: Publication of Culture and Islamic Guidance of State, 2007, p56.

[16] Saaidi P. Budget and Budgeting, first Edition, Tehran: Negah Danesh Publications, 2005.

[17] The World Bank. Public Expenditure Management Handbook. Washington D.C, 1998.

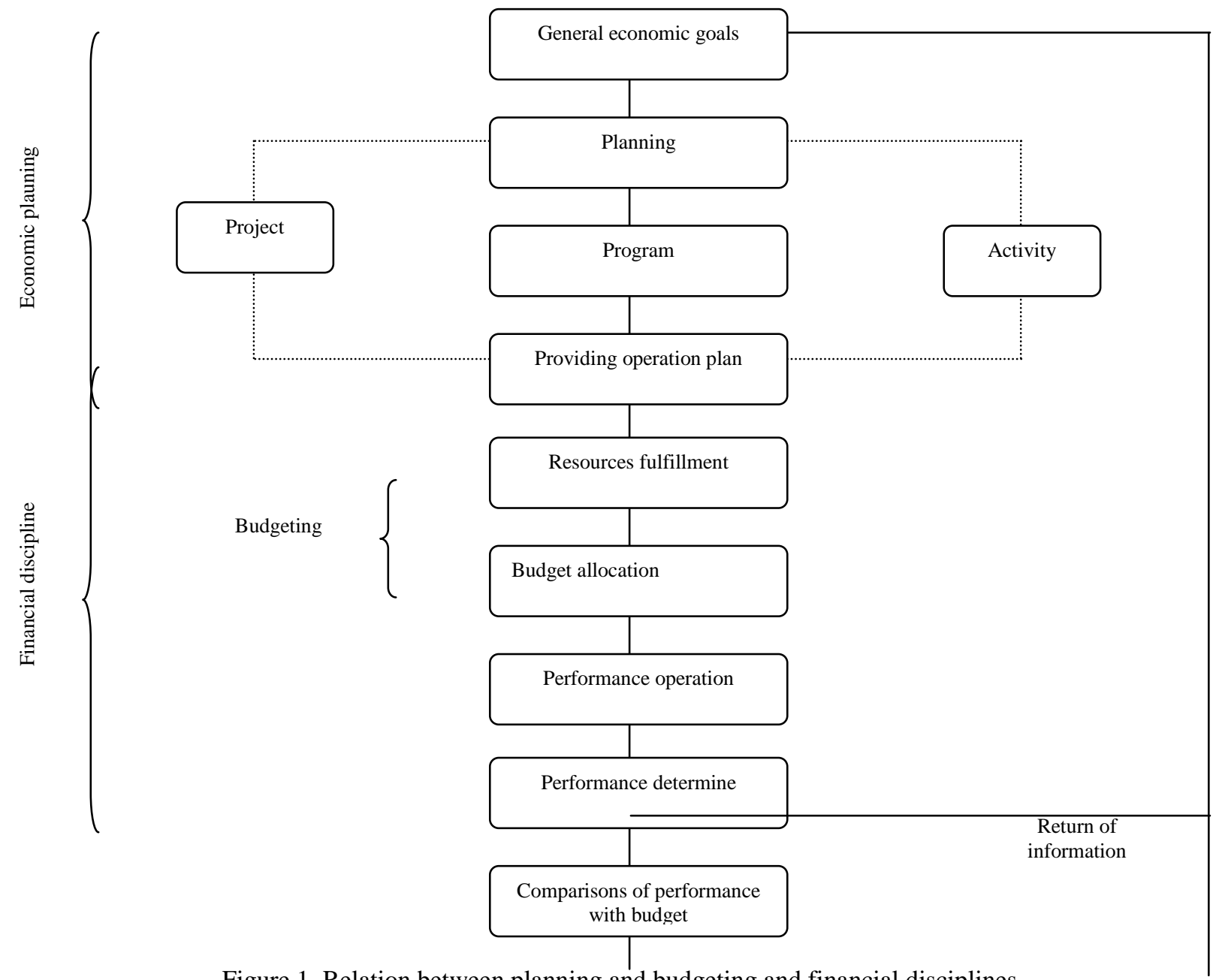

Figure 1. Relation between planning and budgeting and financial disciplines. 